\title{
The Impact of Chief Executive Officer Power on the Agency Costs: Evidence from Libya
}

\section{Moutaz A.Kablan}

Associate Professor - Accounting Division - Faculty of Economics - University of Benghazi Financial Accounting, Benghazi, Libya, Corresponding Author: Moutaz A.Kablan, Associate Professor - Accounting Division - Faculty of Economics - University of Benghazi Financial Accounting, Benghazi, Libya,

Received date: January 02, 2021; Accepted date: March 01, 2021; Published date: March 12,2021

Citation: Moutaz A.Kablan., (2021) The Impact of Chief Executive Officer Power on the Agency Costs: Evidence from Libya. J. Neuroscience and Neurological Surgery. 8(2); DOI:10.31579/2578-8868/157

Copyright: () 2021 Moutaz A.Kablan, This is an open-access article distributed under the terms of The Creative Commons Attribution License, which permits unrestricted use, distribution, and reproduction in any medium, provided the original author and source are credited

\begin{abstract}
Given that the importance of stabilization of the agency theory as a base to organize the relationship between the shareholders "the origin" and the management "the agent" in the business environment nowadays, this study aimed to identify the impact of the chief executive officer "CEO" power on the agency costs in the Libyan private banks. To achieve this goal the study underlying the scarcity of related previous studies has stated its hypotheses. The study sample consists of (6) private banks for (5) years; then the study relied upon the multiple regression technique, which has been used to examine the fourth sub-hypotheses of the main one. As a result, the study became able to state that there is a positive significant relationship between the CEO ownership in the bank shares and the agency costs, while that there is no significant relationship between the duality of CEO role, the duration of CEO in his position, the independency of the board of directors and the agency costs in the Libyan private banks.
\end{abstract}

Keywords: agency costs; ceo power; agency theory.

\section{Introduction:}

At the outset, the agency theory idea presents the special relationship between the shareholders as the origin and the board of directors with all its relatives as the agent, who has the accreditation to invest their assets to maximize the firm value through time.

Although the propagation of this model as a basis to the complete independence between them through the spreading of shareholders companies except that there are some obstacles which have appeared as a case of the asymmetry information called agency costs [1].

Asymmetry information means that the agent has more deep information about the expected events and another sensitive insider information than the origin, so this flow will create a difficulty to monitor the agent performance fairly by the congress of owners [2]

Underlying this contradictoriness between this couple, the role of the chief executive officer "CEO" may affect negatively on agency costs, this is because that the CEO is the top of the executive management of the firm, so the agency theory believes that will never pursue toward maximization the returning of shareholders unless is available on appropriate corporate governance [3].

Speaking of the private banks in Libya, there are multi pure private banks have appeared in the Libyan economy consistent with the recent legislation which encourages this trend, but at the same time, these banks have suffered of multi crises during the last two decades, one of them is the agency costs problems.
And digression by mention of CEO exclusively of the authority of all managers compliance at the firm for all decisions by him. [4,5] indicate that there are four main sources that cause the $\mathrm{CEO}$ power like following:

- Structural Power: May this is the most common type of CEO power which relies upon the organizational structure, so that grants the CEO a high level of the authority against the rest of executive positions of the firm.

- Ownership Power: There is a type of CEO power is generated by his ownership of the firm shares.

- Expert Power: This power represents the CEO accumulative skills to face unexpected and emergency cases in business environment. Due to all the components like clients, suppliers, competitors and the governmental policies may create uncertain situation for the firm, So whensover the $\mathrm{CEO}_{s}$ develop their communications and relationships they will be more effective to conduct against theses irregular crises.

- Prestige Power: Can be considered that the prestige of CEO personality is a vital source of power inspiration, so it affects positively on the CEO reputation in the eyes of the related parts of the firm.

Despite of, there are confirmations of the agency theory to the necessity of reducing the dominance of CEO about all conducts in the firm which targeted to avoid the negative impacts for this progressive power, but it must be acknowledged that there are multi benefits of that like idea response toward the emergency and expected cases [6].

From this point on, we can state that this controversial issue stills needs a lot of researches and studies, additionally; there are multi vital questions 
about the economic impacts of the progression of the $\mathrm{CEO}_{\text {s }}$ power into their firms.

Accordingly, this study tries to answer the following question: what is the impact of the CEO power on agency costs at the Libyan private banks?

Literature Review and Hypotheses Development:

There are many studies aimed to identify the factors those which affect negatively on agency costs. So, consistent with that and what have mentioned above about the question of study, the author will outline some of previous studies regarding to our study.

As what has mentioned before, the majority of the previous studies have stated that there are four main sources of CEO power: structural power, ownership power, expert power and prestige power, the study will present a summary of previous studies relying upon trend.

In the same direction, the study of [7] has determined the assets turn ratio to measure the agency cost as a dependent variable. The study outlined that there is non-significant relationship between the percentage of nonexecutive members in the board of directors and the agency costs. In addition, [8] have resulted that there is a positive relationship between the CEO ownership in the firm and the agency costs.

On other hand, [9] have presented different evidence about the relationship between the duration of CEO and the agency cost, due to the result ensured that there is a negative relationship between them.

Talking about the recent related studies, [10] has resulted in there is a negative relationship between the percentage of non-executive members in the board of directors and the agency costs, which measured by the assets turn ratio and the percentage of managerial expenses to the total of sales.

By digression, the study of [11] has stabilized to there is no significant relationship between the percentage of non-executive members of the board and the agency costs which measured by the two previous variables which were chosen by the last study.

From this point, due to the variance of the expectations about the impact of CEO power on the agency costs, the study became able to state the main hypothesis like the following:

\section{H: There is no significant relationship between CEO power and the agency costs in the Libyan private banks.}

Due to the CEO power sources as stated earlier, the study has derived the following four sub-hypotheses to examine the main one:

H1: There is no a significant relationship between the duality of CEO role and the agency costs in the Libyan private banks.

$\mathbf{H}_{2}$ : There is no a significant relationship between the duration of CEO in his position and the agency costs in the Libyan private banks.

$\mathbf{H}_{3}$ : There is no a significant relationship between the CEO ownership in the bank's shares and the agency costs in the Libyan private banks.

$\mathbf{H}_{4}$ : There is no a significant relationship between the independency of the board of directors and the agency costs in the Libyan private banks.

\section{The Importance of Study:}

This study provides multi advantages to the investors due to getting acquainted with the impacts of growing the infiltration of CEO on the agency contract between the management and the shareholders which leading to make their investment decisions mature. Additionally, as far as the author knows this study considered as the first one in the Libyan business environment which tries to identify the impact of CEO power on agency costs.

\section{The Aim of Study:}

This study mainly aims to identify the impact of CEO power on the agency costs at the Libyan private banks to present an applied evidence about the nature of this impact.

\section{The methodology of study:}

At first, the methodology presents all the steps during the trail either theoretical or applied aspects alike, so this section contents of the following sub-contents:

\section{The method of study:}

This study is based upon the inductive approach, whereas it has reviewed the related previous studies, the study has stated its main hypothesis and the four sub-hypotheses. Accordingly, the study has relied on deductive approach by statistical analysis to examine these hypotheses, to finally reach the findings and conclusion.

\section{The Applied Aspect:}

This section consists of the following sub-sections:

\section{The population and Sample of Study:}

The population of study consists of all the Libyan private banks, were they are shareholding companies basically. As for talking about the sample, it consists of the Libyan private banks which provide their published financial reports, additionally the external auditor report about the duration (2010-2014). These five years is the main condition to make the applied aspect complete relying upon the time series analysis.

Consequently, the purposive sample of study is shown in table (1) like following:

\begin{tabular}{|c|l|}
\hline No & \multicolumn{1}{|c|}{ The Bank } \\
\hline 1 & Bank of Commerce and Development \\
2 & ATIB Bank \\
3 & The Mediterranean Bank \\
4 & Alejmaa Bank \\
5 & The United Bank \\
6 & Alwaha Bank \\
\hline \multicolumn{2}{|c|}{ Table 1: The sample of study } \\
\hline
\end{tabular}

\section{(5-2-2) The Limitations of Study:}

As an applied study, this study relies upon the actual historical data about the sample for five years (2010-2014) to identify what is the impact of chief executive officer power in the Libyan private banks only "excluding the public ones" on the agency costs.

\section{(5-2-3) The Sources of Data:}

The applied aspect of study is based upon the published financial statements with the report of external auditor for theses all banks alike. In addition, the study relies on the authorized additional data like: whether CEO is the chairman of the board or not, whether the duration of CEO as a chairman of the board over than three years or not, whether the percentage of CEO ownership in the company's shares equals or more than $5 \%$ or not, and where the percentage of non-executive members in the board of directors less than $50 \%$ or not. 


\section{(5-2-4) The Testing of Hypotheses:}

The author has entered the data of study by statistical package for the social sciences "SPSS" software to test the hypotheses of study by multiple regression analysis technique as a one of parametric tests, then the results and the conclusion will be presented alike.

To achieve this goal, the study has relied upon the literature review to state its hypothesis "in null form" as mentioned earlier, then the author has formulated the equation of the main hypothesis consistently with the requirements of multiple regression technique like following:

Agency Costs (it) $=\mathrm{B}_{0}+\mathrm{B}_{1} \mathrm{CEO}$ power (it) $+\mathrm{B}_{2}$ board size (it) $+\mathrm{B}_{3}$ bank size (it) $+\mathrm{B}_{4}$ dividends (it) $+\mathrm{B}_{5}$ bgo(it) $+\mathrm{B}_{6}$ lev (it) $+\sum$ (it) ........... (1)

And toward deriving the independent variable "CEO power" to its four sub-independent variables, the modified equation will be like the following:

Agency Costs (it) $=\mathrm{B}_{0}+\mathrm{B}_{1}$ CEO dual (it) $+\mathrm{B}_{2}$ CEO dura (it) $+\mathrm{B}_{3}$ CEO own (it) $+\mathrm{B}_{4}$ board ind (it) $+\mathrm{B}_{5}$ board size (it) $+\mathrm{B}_{6}$ bank size (it) + $B_{7}$ dividends (it) $+B_{8}$ bgo (it) $+B_{9}$ lev (it) $+\sum$ (it) .

\section{Knowing that:}

- Agency Costs (it): Agency costs of bank (i) about year (t).... The dependent variable

- CEO power (it): The CEO power of bank (i) about year (t).... The main independent variable.

- $\quad$ CEO dual (it): The duality of CEO role of bank (i) during year ( $t$ )... The first sub-independent variable.

- CEO dura (it): The duration of CEO in his position of bank (i) about year $(\mathrm{t}) . .$. The second sub-independent variable.

- $\quad$ CEO own (it): The CEO ownership in the bank's shares of bank (i) about year $(\mathrm{t})$.... The third sub-independent variable.
- $\quad$ Board ind (it): The board of directors independency of bank (i) about year $(\mathrm{t}) . .$. The fourth sub-independent variable.

- Board size (it): The board of directors size of bank (i) about year (t).... The first controlled variable.

- $\quad$ Bank size (it): The size of bank (i) about year (t).... The second controlled variable.

- $\quad$ Dividends (it): The paid cash dividends of bank (i) about year (t)... The third controlled variable.

- $\quad$ Bgo (it): The bank growth opportunities of bank (i) about year (t)... The fourth controlled variable.

- $\quad$ Lev (it): The financial leverage of bank (i) about year ( $t$ ).... The fifth controlled variable.

In addition, the study has stated the coming four models to test the four sub-hypotheses of the main one:

Agency Costs (it) $=B_{0}+B_{1}$ CEO dual (it) $+B_{2}$ board size (it) $+B_{3}$ bank size (it) $+\mathbf{B}_{4}$ dividends (it) $+\mathbf{B}_{5}$ bgo (it) $+\mathbf{B}_{6}$ lev (it) $+\sum$ (it) $\ldots \ldots \ldots \ldots$.... (11)

Agency Costs (it) $=B_{0}+B_{1}$ CEO dura $($ it $)+B_{2}$ board size (it) $+B_{3}$ bank size (it) $+\mathrm{B}_{4}$ dividends (it) + $\mathrm{B}_{5}$ bgo (it) $+\mathrm{B}_{6}$ lev (it) $+\sum$ (it) ........... (12)

Agency Costs $(i t)=B_{0}+B_{1}$ CEO own (it) $+B_{2}$ board size (it) $+B_{3}$ bank size (it) $+\mathrm{B}_{4}$ dividends (it) $+\mathrm{B}_{5}$ bgo (it) $+\mathrm{B}_{6}$ lev (it) $+\sum$ (it) $\ldots \ldots \ldots \ldots$ (13)

Agency Costs (it) $=B_{0}+B_{1}$ board ind (it) $+B_{2}$ board size (it) $+B_{3}$ bank size (it) $+B_{4}$ dividends (it) $+B_{5}$ bgo (it) $+B_{6}$ lev (it) $+\sum$ (it) $\ldots \ldots \ldots \ldots$ (14)

\section{(5-2-5) The variables of study and How to measure them:}

To achieve the statistical aspect of study, the author will rely upon assets turn ratio to measure the agency costs of the bank, so the following two (Tables 2,3) illustrate each variable and how to measure it:

\begin{tabular}{|c|c|c|}
\hline The Variable & The Type & How to Measure It \\
\hline $\begin{array}{l}\text { Agency Costs } \\
\text { (it) }\end{array}$ & The dependent variable & $\begin{array}{l}\text { By assturn }=\text { the annual revenues of bank (i) } \div \text { the book value } \\
\text { of assets at the end of year (t) }\end{array}$ \\
\hline CEO power(it) & $\begin{array}{l}\text { The main independent } \\
\text { variable }\end{array}$ & $\begin{array}{l}\text { By an indicator which consists of four sub-independent variables } \\
\text { like following: CEO dual, CEO dura, CEO own and board ind }\end{array}$ \\
\hline CEO dual (it) & $\begin{array}{l}\text { The first sub-independent } \\
\text { variable }\end{array}$ & $\begin{array}{l}\text { A fake variable, takes (1) whether the CEO is the chairman of } \\
\text { the board of directors of bank (i) about year (t), while takes }(0) \\
\text { in otherwise }\end{array}$ \\
\hline CEO dura (it) & $\begin{array}{l}\text { The second sub- } \\
\text { independent variable }\end{array}$ & $\begin{array}{l}\text { Measured by the numbers of years which have been spent by } \\
\text { CEO in his position in bank (i) }\end{array}$ \\
\hline CEO own (it) & $\begin{array}{l}\text { The third sub-independent } \\
\text { variable }\end{array}$ & $\begin{array}{l}\text { Measured by dividing the number of the CEO'S shares on the } \\
\text { total current shares of the bank (i) about year ( } t \text { ) }\end{array}$ \\
\hline Board ind (it) & $\begin{array}{l}\text { The fourth sub- } \\
\text { independent variable }\end{array}$ & $\begin{array}{l}\text { Measured by a fake variable which takes (1) whether the } \\
\text { percentage of the non-executive members in the board of bank } \\
\text { (i) about year (t) is greater than } 50 \% \text { of the total members, while } \\
\text { takes (0) in otherwise }\end{array}$ \\
\hline
\end{tabular}

Table 2: The Dependent and Independent variables of study and How to measure them

\begin{tabular}{|l|c|l|}
\hline \multicolumn{1}{|c|}{ The Variable } & \multicolumn{1}{|c|}{ The Type } & \multicolumn{1}{c|}{ How to Measure It } \\
\hline Board size (it) & $\begin{array}{c}\text { The first controlled } \\
\text { variable }\end{array}$ & $\begin{array}{l}\text { Measured by the number of members of the board of directors of } \\
\text { bank (i) about year (t) }\end{array}$ \\
\hline Bank size (it) & $\begin{array}{c}\text { The second controlled } \\
\text { variable }\end{array}$ & $\begin{array}{l}\text { Measured by the natural logarithm of the total assets of bank (i) } \\
\text { about year (t). }\end{array}$ \\
\hline
\end{tabular}




\begin{tabular}{|l|c|l|}
\hline Dividends (it) & \multicolumn{1}{|c|}{$\begin{array}{c}\text { The third controlled } \\
\text { variable }\end{array}$} & $\begin{array}{l}\text { Measured by dividing the paid cash dividends by bank (i) on the } \\
\text { total book value of its assets at the end of year (t) }\end{array}$ \\
\hline Bgo (it) & $\begin{array}{c}\text { The fourth controlled } \\
\text { variable }\end{array}$ & $\begin{array}{l}\text { Measured by the percentage of the market value of assets of bank } \\
\text { (i) to the book value of these assets at the end of year ( } \mathrm{t} \text { ) }\end{array}$ \\
\hline $\begin{array}{c}\text { Lev (it) } \\
\text { The fifth controlled } \\
\text { variable }\end{array}$ & $\begin{array}{l}\text { Measured by dividing the total of liabilities of bank (i) on the total } \\
\text { book value of its assets at the end of year (t) }\end{array}$ \\
\hline
\end{tabular}

Table 3: The Controlled variables of study and How to measure them

\section{An Important Note:}

Take in your concern that the percentage of the assets turn ratio will be entered through the statistical analysis subtrahended of $100 \%$, this is because the increasing of this percentage means decreasing in agency costs, and vice versa.

\section{(5-2-6) The Results of Applied study:}

First and foremost, the author has relied upon Kolmogorov smirnov test to identify whether the collected data are normally distributed or not.

- The Results of "Kolmogorov- smirnov" test:

According to table (4) the results of test illustrate that the data are normally distributed "parametric", due to the Asymp. Sig "pvalues" of all variables are greater than " $\alpha=0.05$ ".

\begin{tabular}{|l|c|c|}
\hline \multirow{2}{*}{ Variables } & \multicolumn{2}{|c|}{ One sample Kolmogorov- smirnov } \\
\cline { 2 - 3 } & Kolmogorov-Z & Asymp. Sig \\
\hline Agency & 1.399 & 0.218 \\
costs & 0.932 & 0.251 \\
CEO dual & 0.890 & 0.817 \\
CEO dura & 1.861 & 0.909 \\
CEO own & 0.723 & 0.553 \\
Board ind & 0.867 & 0.267 \\
Board & 0.452 & 0.318 \\
size & 0.652 & 0.412 \\
Bank size & 0.702 & 0,781 \\
Dividends & 0.621 & 0.610 \\
Bgo & & \\
Lev & & \\
\hline
\end{tabular}

Table 4: Kolmogorov- smirnov test
- The Descriptive Analysis:

Table (5) shows the means, standard deviations, and the highest and lowest values of all study's variables.

\begin{tabular}{|l|c|c|c|c|c|}
\hline Variables & N & Mean & Std deviation & Min & Max \\
\hline Agency & 120 & 7.123 & 0.716 & 1.832 & 14.207 \\
costs & 120 & 15.102 & 3.890 & 11.207 & 19.813 \\
CEO dual & 120 & 14.215 & 2.909 & 15.333 & 19.958 \\
CEO dura & 120 & 9.121 & 0.617 & 0.001 & 16.919 \\
CEO own & 120 & 7.202 & 3.821 & 5.123 & 21.926 \\
Board ind & 120 & 8.197 & 1.707 & 16.671 & 18.845 \\
Board size & 120 & 6.539 & 0.946 & 0.891 & 17.851 \\
Bank size & 120 & 4.505 & 0.357 & 5.267 & 18.523 \\
Dividends & 120 & 5.112 & 1.202 & 2.891 & 10.851 \\
Bgo & 120 & 3.291 & 0.999 & 5.971 & 20.820 \\
Lev & \multicolumn{7}{|c|}{ Table 5: The Descriptive Analysis } \\
\hline
\end{tabular}

- The Results of Testing of The first sub-Hypothesis:

$\mathrm{H}_{1}$ : There is no a significant relationship between the duality of CEO role and the agency costs in the Libyan private banks.

\begin{tabular}{|c|c|c|c|c|}
\hline$\beta$ & t-value & Sig. & Adjusted $\mathbf{R}^{2}$ & \\
\hline 0.017 & 0.031 & 0.590 & $\% 36.5$ & \\
\hline \multicolumn{4}{|c|}{$\begin{array}{l}\text { Agency Costs (it) }=\mathrm{B}_{0}+\mathrm{B}_{1} \mathrm{CEO} \text { dual (it) }+\mathrm{B}_{2} \text { board size (it) }+\mathrm{B}_{3} \text { bank size (it) }+\mathrm{B}_{4} \text { dividends (it) } \\
+\mathrm{B}_{5} \text { bgo (it) }+\mathrm{B}_{6} \text { lev (it) }+\sum \text { (it) }\end{array}$} & $(1-1)$ \\
\hline
\end{tabular}

Table 6: The Results of Testing of the first sub-Hypothesis

According to the statistical analysis of model (1-1), the study has concluded that, there is no significant correlation relationship between the duality of CEO core and the agency costs in the Libyan private banks.

Where, calculated $(p-$ value $=0.590)>(\alpha=0.05)$, so this sub-independent variable doesn't affect on the dependent variable "agency costs".
Consequently, the study rejected this sub-hypothesis $\left(\mathrm{H}_{1}\right)$.

\section{- The Results of Testing of The second sub-Hypothesis:}

$\mathrm{H}_{2}$ : There is no a significant relationship between the duration of CEO in his position and the agency costs in the Libyan private banks.

\begin{tabular}{|c|c|c|c|}
\hline $\boldsymbol{\beta}$ & t-value & Sig. & Adjusted $\mathbf{R}^{2}$ \\
\hline 0.013 & 0.028 & 0.510 & $\% 29.5$ \\
\hline $\begin{array}{l}\text { Agency Costs (it) }=\mathrm{B}_{0}+\mathrm{B}_{1} \mathrm{CEO} \text { dura (it) }+\mathrm{B}_{2} \text { board size (it) }+\mathrm{B}_{3} \text { bank size (it) }+\mathrm{B}_{4} \text { dividends (it) } \\
+\mathrm{B}_{5} \text { bgo (it) }+\mathrm{B}_{6} \text { lev (it) }+\sum \text { (it) }\end{array}$ & (1-2) \\
\hline
\end{tabular}

Table 7: The Results of Testing of the second sub-Hypothesis 
According to the statistical analysis of model (1-2), the study has concluded that, there is no significant correlation relationship between the duration of CEO in his position and the agency costs in the Libyan private banks.

Where, calculated $(p-$ value $=0.510)>(\alpha=0.05)$, so this sub-independent variable doesn't affect on the dependent variable "agency costs".
Consequently, the study rejected this sub-hypothesis $\left(\mathrm{H}_{2}\right)$.

\section{- The Results of Testing the Third sub-Hypothesis:}

$\mathrm{H}_{3}$ : There is no a significant relationship between the CEO ownership in the bank's shares and the agency costs in the Libyan private banks.

\begin{tabular}{|c|c|c|c|}
\hline $\boldsymbol{\beta}$ & t-value & Sig. & Adjusted R \\
\hline 0.995 & 6.43 & 0.0001 & $\% 93.5$ \\
\hline $\begin{array}{l}\text { Agency Costs (it) }=\mathrm{B}_{0}+\mathrm{B}_{1} \text { CEO own (it) }+\mathrm{B}_{2} \text { board size (it) }+\mathrm{B}_{3} \text { bank size (it) }+\mathrm{B}_{4} \text { dividends (it) } \\
+\mathrm{B}_{5} \text { bgo (it) }+\mathrm{B}_{6} \text { lev (it) }+\sum \text { (it) }\end{array}$ & (1-3) \\
\hline
\end{tabular}
$N=120, \alpha=0.05$

Table 8: The Results of Testing the Third sub-Hypothesis

According to the statistical analysis of model (1-3), the study has concluded that (adjusted $\mathrm{R}^{2}=0.935$ ), this means that \%93.5 of the happened changes in agency costs in Libyan private banks can be explained by the CEO ownership in the bank's shares.

In addition, the results of statistical analysis confirm the significance of this effect, where that the calculated $(p$-value $=0.0001)<(\alpha=0.05)$, so this sub-independent variable significantly affects positively on the dependent variable "agency costs". So to test this model, the study has used " $\mathrm{t}$ " test, then the factor $=0.995$ and $\mathrm{t}$-value $=6.48$.
This means that the CEO ownership in the bank's shares has a positive significant effect on agency costs.

Based on all of above, the study accepted this sub-hypothesis.

\section{- The Results of Testing the Fourth sub-Hypothesis:}

$\mathrm{H}_{4}$ : There is no a significant relationship between the independency of the board of directors and the agency costs in the Libyan private banks.

\begin{tabular}{|c|c|c|c|}
\hline $\boldsymbol{\beta}$ & t-value & Sig. & Adjusted $\mathbf{R}^{\mathbf{2}}$ \\
\hline 0.017 & 0.037 & 0.530 & $\% 39$ \\
\hline
\end{tabular}

Table 9: The Results of Testing the Fourth sub-Hypothesis:

According to the statistical analysis of model (1-4), the study has concluded that, there is no significant correlation relationship between the independency of the board of directors and the agency costs in the Libyan private banks.

Where, calculated $(p-$ value $=0.530)>(\alpha=0.05)$, so this sub-independent variable doesn't affect on the dependent variable "agency costs".

Consequently, the study rejected this sub-hypothesis $\left(\mathrm{H}_{4}\right)$.

\section{The summarized Results:}

It is possible to summarize the applied results like following:

- The duality of CEO role does not have a significant effect on the agency costs in the Libyan private banks.

- The duration of CEO in his position does not have a significant effect on the agency costs in the Libyan private banks.

- The CEO ownership in the bank's shares has a positive significant effect on the agency costs in the Libyan private banks.

- The independency of the board of directors of the bank does not have a significant effect on the agency costs in the Libyan private banks.

\section{Conclusion:}

Due to this study aimed to identify the impact of the chief executive officer power in the Libyan private banks as an independent variable, the author has derived this power to four sub-independent variables like following: the duality of CEO role, the duration of CEO in his position, the CEO ownership in bank's shares and the independency of the board of directors of the bank.

As a result, after the execution of the applied aspect, the study has resulted that there is no significant relationship between the first, the second, the fourth sub-independent variables and the agency cots in the Libyan private banks. While there is a positive significant relationship between the third sub-independent variable "the CEO ownership in the bank's shares" and the dependent variable of the study "the agency costs in the Libyan private banks".

\section{References:}

1) Moez, D. (2018), Agency Costs, Corporate Governance and the Nature of Controlling shareholders: Evidence from French Listed Firms, International Journal of Accounting and Financial Reporting, 8 (3), 256-277.

2) Owusu, A., \& Weir, C. (2017), Agency Costs, Ownership Structure \& Corporate Governance Mechanisms in Ghana, International Journal of Accounting, Auditing \& Performance Evaluation, 14 (1), 63-84.

3) Semenenko, I \& Yoo, J. (2019), Annual Reporting, Agency Costs, and Firm Valuation, Journal of Corporate Accounting and Finance, 31 (1), 133 - 154.

4) Finkelsteim, S. (1992), Power in Top Management Team: Dimensions, Measurement, and Validation, Academy of Management Journal, 35(3), 505-538.

5) Tang, J., Grossan, M \& Rowe, W. (2011), Dominant CEO, Deviation Strategy \& Extreme Performance: The Moderating Role of A 
Powerful Board, Journal of Management Studies, 48(7), 14791503.

6) Nguyen, A., Doan, D \& Nguyen, L. (2020), Corporate Governance \& Agency Costs: Empirical Evidence from Vietnam, Journal of Risk \& Financial Management, 13 (5), 89-103.

7) Singh, M \& Davidson, W. (2003), Agency Costs, Ownership Structure \& Corporate Governance Mechanism, Journal of Banking \& Finance, 27 (3), 88-95.

8) Davidson, W. (2006), Agency Costs, Ownership Structure \& Corporate Governance in Pre-and Post- Idol Firms, Corporate Ownership \& Control, 3 (3), 88-95.
9) Mcknight, P \& Weir, C. (2009), Agency Costs, Corporate Governance Mechanisms \& Ownership Structure in Large UK Publicly Quoted Companies: A Panel Data Analysis, The Quarterly Review of Economics and Finance, 49 (2), 139-159.

10) Moez, D. (2018), Agency Costs, Corporate Governance \& Nature of Controlling Shareholders: Evidence from French Listed Firms, International Journal of Accounting and Finance Reporting, 8 (3), 256-277.

11) Lassoued, NA., Attia, M. and Sassi, H. (2019), Agency Costs, Ownership \& International Governance Mechanisms: Evidence from Chines Listed Companies, Asian Economic \& Financial Review, 9 (1), 133-154.
This work is licensed under Creative Commons Attribution 4.0 License

To Submit Your Article Click Here: Submit Manuscript

DOI: $10.31579 / 2578-8868 / 157$
Ready to submit your research? Choose Auctores and benefit from:

* fast, convenient online submission

* rigorous peer review by experienced research in your field

* rapid publication on acceptance

* authors retain copyrights

* unique DOI for all articles

* immediate, unrestricted online access

At Auctores, research is always in progress.

Learn more www.auctoresonline.org/journals/neuroscience-andneurological-surgery 